\title{
Legumes increase grassland productivity with no effect on nitrous oxide emissions
}

\author{
Arlete S. Barneze $\mathbb{D}$ - Jeanette Whitaker • \\ Niall P. McNamara • Nicholas J. Ostle
}

Received: 26 March 2019 /Accepted: 15 October 2019/Published online: 16 November 2019

(C) The Author(s) 2019

\begin{abstract}
Aims Grasslands are important agricultural production systems, where ecosystem functioning is affected by land management practices. Grass-legume mixtures are commonly cultivated to increase grassland productivity while reducing the need for nitrogen $(\mathrm{N})$ fertiliser. However, little is known about the effect of this increase in productivity on greenhouse gas (GHG) emissions in grass-legume mixtures. The aim of this study was to investigate interactions between the proportion of legumes in grass-legume mixtures and N-fertiliser addition on productivity and GHG emissions. We tested the hypotheses that an increase in the relative proportion of legumes would increase plant productivity and decrease GHG emissions, and the magnitude of these effects would be reduced by $\mathrm{N}$-fertiliser addition.

Methods This was tested in a controlled environment mesocosm experiment with one grass and one legume species grown in mixtures in different proportions, with or without $\mathrm{N}$-fertiliser. The effects on $\mathrm{N}$ cycling
\end{abstract}

Responsible Editor: Martin Weih.

Electronic supplementary material The online version of this article (https://doi.org/10.1007/s11104-019-04338-w) contains supplementary material, which is available to authorized users.

A. S. Barneze $(\bowtie) \cdot$ N. J. Ostle

Lancaster Environment Centre, Lancaster University,

Lancaster LA1 4YQ, UK

e-mail: arletesb@gmail.com

A. S. Barneze · J. Whitaker · N. P. McNamara

Centre for Ecology \& Hydrology, Lancaster Environment Centre,

Library Avenue, Bailrigg, Lancaster LA1 4AP, UK processes were assessed by measurement of aboveand below-ground biomass, shoot $\mathrm{N}$ uptake, soil physico-chemical properties and GHG emissions.

Results Above-ground productivity and shoot $\mathrm{N}$ uptake were greater in legume-grass mixtures compared to grass or legume monocultures, in fertilised and unfertilised soils. However, we found no effect of legume proportion on $\mathrm{N}_{2} \mathrm{O}$ emissions, total soil $\mathrm{N}$ or mineral-N in fertilised or unfertilised soils.

Conclusions This study shows that the inclusion of legumes in grass-legume mixtures positively affected productivity, however $\mathrm{N}$ cycle were in the short-term unaffected and mainly affected by nitrogen fertilisation. Legumes can be used in grassland management strategies to mitigate climate change by reducing crop demand for $\mathrm{N}$-fertilisers.

Keywords Grass-legume mixture · Nitrogen fertiliser . Carbon and nitrogen cycling · Plant productivity .

Greenhouse gas emissions

\section{Introduction}

Grasslands provide important ecosystem services worldwide. These include sequestering carbon (C) in plant biomass and soil organic matter, and producing the majority of forage for ruminants (De Deyn et al. 2008). Grassland species composition has been shown to be an important driver of these ecosystems functions (Bardgett 2011; De Deyn et al. 2009; Loreau and Hector 2001; Tilman et al. 2001) due to plant-plant and plant- 
soil interactions. The relationship between plant diversity and productivity can affect plant-soil feedbacks, e.g. through the availability of mineral nutrients in the soil. While the effects of grassland species composition has been widely studied in relation to a range of ecosystem services (Niklaus et al. 2006), its influence on greenhouse gas (GHG) emissions is relatively unexplored, especially for nitrous oxide $\left(\mathrm{N}_{2} \mathrm{O}\right)$ and methane $\left(\mathrm{CH}_{4}\right)$ (Abalos et al. 2014; Abalos et al. 2018; Sun et al. 2013) which are important agricultural GHGs with greater warming potential.

Grass-legume mixtures are commonly used for grazing because they offer the potential to increase productivity with a lower requirement for costly and polluting nitrogen $(\mathrm{N})$ fertilisers. Legumes not only provide high quality forage due to their high fibre and protein content (Mortenson et al. 2004), but also promote symbiotic $\mathrm{N}_{2}$ fixation thereby producing more protein with less $\mathrm{N}$ input (Suter et al. 2015). The use of mixtures has been shown to increase plant productivity through increases in resource uptake efficiency due to: i) $\mathrm{N}$ transfer from legumes to grasses (Høgh-Jensen and Schjoerring 1997; Pirhofer-Walzl et al. 2012), and/or ii) species differences in root structure increasing the exploitation of soil resources (Mueller et al. 2013; van Ruijven and Berendse 2005). As a consequence, legume-based cropping can reduce $\mathrm{N}$ losses from soil via leaching (Drinkwater et al. 1998; Li et al. 2016) and increase $C$ sequestration due to increased plant $C$ inputs (De Deyn et al. 2011).

Increases in the proportion of legumes may also influence plant-soil GHG emissions through alterations to $\mathrm{C}$ and $\mathrm{N}$ cycling processes, something scarcely addressed in experimental studies. This effect is likely to differ in unfertilised and fertilised soils due to impacts on $\mathrm{C}$ and $\mathrm{N}$ availability (Bardgett et al. 1999; Oertel et al. 2016; Thomson et al. 2012). In unfertilised soils, legumes will enhance plant productivity via symbiotic $\mathrm{N}_{2}$ fixation, which may reduce mineral-N availability in the soil and decrease soil $\mathrm{N}_{2} \mathrm{O}$ emissions. Alternatively, increases in the proportion of legumes might increase mineral-N in soil, especially $\mathrm{NO}_{3}{ }^{-}$, due to the release of fixed $\mathrm{N}$ from legume roots via decomposition and the inefficiency of legumes in acquiring soil mineral- $\mathrm{N}$ (Niklaus et al. 2006), which could promote soil $\mathrm{N}_{2} \mathrm{O}$ emissions. In fertilised and unfertilised soils an additional mechanism for $\mathrm{N}_{2} \mathrm{O}$ emission from legumes could be direct $\mathrm{N}_{2} \mathrm{O}$ production from the biological $\mathrm{N}$ fixation process itself but this is considered a relatively small source of $\mathrm{N}_{2} \mathrm{O}$ emissions (Carter and Ambus 2006). In fertilised soils, legume growth may be suppressed promoting the dominance of grasses (De Deyn et al. 2011; Ledgard 2001; Smith et al. 2008), with effects on $\mathrm{N}_{2} \mathrm{O}$ emissions driven by the magnitude of $\mathrm{N}$ addition rather than legume proportion itself. Alternatively, increases in legume proportion may reduce plant $\mathrm{N}$ uptake (due to increase $\mathrm{N}_{2}$ fixation), leading to higher mineral- $\mathrm{N}$ in the soil (Niklaus et al. 2006). Overall, the effect of increases in legume proportions on soil $\mathrm{N}_{2} \mathrm{O}$ emissions will potentially reflect the balance between $\mathrm{N}$ uptake by plants and mineral-N availability in the soil. While legumes are well known to contribute to plant productivity, their effect on soil $\mathrm{N}_{2} \mathrm{O}$ emissions is less studied.

Introducing legumes into grasslands can increase plant productivity and alter the quality and quantity of plant $\mathrm{C}$ and $\mathrm{N}$ inputs to the soil (De Deyn et al. 2009; Fornara and Tilman 2008). In fertilised grassland soils, an increase in the proportion of legumes reduced microbial and root respiration and ecosystem respiration, which was associated with increases in $\mathrm{C}$ and $\mathrm{N}$ accumulation through input of nutrients to the soil (De Deyn et al. 2011). Likewise, in unfertilised soils, the inclusion of legumes in grass-legumes mixtures might promote the reduction of ecosystem respiration due to the increase of above- and below-ground biomass, which showed a positive relationship with $\mathrm{C}$ and $\mathrm{N}$ storage in the soil (Wu et al. 2017). Given that $\mathrm{C}$ and $\mathrm{N}$ cycling are closely related, $\mathrm{CH}_{4}$ fluxes can also be affected by grasslegume mixtures. $\mathrm{CH}_{4}$ fluxes depend on the balance between the production by methanogenic bacteria and the consumption by methanotrophic bacteria (Chistoserdova et al. 2005; Le Mer and Roger 2001), and grassland soils generally act as a sink of $\mathrm{CH}_{4}$. In fertilised soils, the increase of $\mathrm{N}$ mineral in the soil, especially $\mathrm{NH}_{4}{ }^{+}$, may alter the production/ consumption of $\mathrm{CH}_{4}$ in the soils, because $\mathrm{NH}_{4}^{+}$competes with $\mathrm{CH}_{4}$ at enzymatic levels or as a competitive effect of nitrifiers and methanotrophs (Topp and Pattey 1997). In unfertilised soils, this effect is less evident than in fertilised soils as $\mathrm{NH}_{4}{ }^{+}$concentrations will be lower. The effect of grass-legume mixtures will thus depend on intra- and inter-specific plant competition and facilitation, which in turn may affect biological $\mathrm{N}_{2}$ fixation, community productivity (Kirwan et al. 2007; Nyfeler et al. 2011) and plant-soil GHG emissions.

In this study we investigated how the proportion of legumes in grass-legume mixtures affected plant productivity and $\mathrm{C}$ and $\mathrm{N}$ cycling in fertilised and unfertilised soils (i.e. inorganic $\mathrm{N}$ ) without necessarily 
accounting for $\mathrm{N}$-fixation. The following specific hypotheses were tested: H1. In unfertilised soil, an increasing proportion of legumes in grass-legume mixtures will i) increase plant productivity and ecosystem respiration, and ii) promote plant $\mathrm{N}$ uptake, reducing $\mathrm{N}_{2} \mathrm{O}$ emissions as a result of lower soil $\mathrm{N}$ availability. $\mathrm{H} 2$. In fertilised soil, $\mathrm{N}$ addition will iii) reduce legume productivity whilst favouring grass productivity, and reduce ecosystem respiration, and iv) with $\mathrm{N}$ addition causing greater $\mathrm{N}_{2} \mathrm{O}$ emissions in all legume-grass combinations.

To test these hypotheses a factorial mesocosm experiment was conducted under controlled environment conditions with one grass and one legume species grown in mixtures with different proportions, with or without $\mathrm{N}$-fertiliser. The effects of grass-legume mixtures and inorganic $\mathrm{N}$ addition on plant-soil $\mathrm{C}$ and $\mathrm{N}$ cycling processes were then assessed through the measurement of above- and below-ground plant productivity, soil nutrient availability and GHG emissions.

\section{Material and methods}

Experimental design

To quantify the interactive effects of $\mathrm{N}$ fertiliser and grass-legume mixtures on $\mathrm{C}$ and $\mathrm{N}$ cycling, a fastgrowing legume species, Trifolium pratense L. (Tr), and a grass species, Agrostis capillaris L., were selected (Emorsgate Seeds, Kings Lynn, UK), both of which commonly occur in managed temperate grasslands across Europe. These plant species are known to differ in their functional traits including average root diameter, specific root length, root dry matter content, leaf $\mathrm{N}$ concentration, and leaf dry matter content (Table S1). Five grass-legume mixtures with $0,25 \%, 50 \%, 75 \%$ and $100 \%$ legume abundance (percentage calculated as number of plants) were superimposed with $\mathrm{N}$ addition treatment resulting in 10 treatments in total. $\mathrm{N}$ was applied at an equivalent rate of $100 \mathrm{~kg} \mathrm{~N} \mathrm{ha}^{-1}$ as $\mathrm{NH}_{4} \mathrm{NO}_{3}$. The experiment was arranged in a fullyrandomised design with five replicates per treatment.

Plastic (PVC) pots (13 cm diameter and $9 \mathrm{~cm}$ depth) were filled with $800 \mathrm{~g}$ soil at $70 \%$ water-filled pore space (WFPS). Topsoil (0-10 cm depth) was collected from a permanent temperate grassland at Hazelrigg, Lancaster University, UK (54 $1^{\circ} 1^{\prime} 50^{\prime} \mathrm{N}, 2.7^{\circ} 46^{\prime} 30^{\prime \prime} \mathrm{W}$, $94.1 \mathrm{~m}$ a.s.1.). This site is a 61 ha area of permanent unfertilised grassland intermittently grazed by sheep and used as a hay meadow. The soil was a silt loam (Brickfield 2 Association; Avis and Harrop (1983)) and contained $25.6 \mathrm{~g}$ total $\mathrm{C} \mathrm{kg}^{-1}, 2.3 \mathrm{~g}$ total $\mathrm{N} \mathrm{kg}^{-1}$, and had a $\mathrm{pH}\left(\mathrm{H}_{2} \mathrm{O}\right)$ of 5.9. Roots and plant fragments were removed, soil was sieved through $8 \mathrm{~mm}$ screen, thoroughly mixed and air-dried at $20^{\circ} \mathrm{C}$ to $70 \%$ WFPS. Soil moisture was gravimetrically maintained every two days in all mesocosm pots.

Prior to the start of the experiment, $T$. pratense and A. capillaris seeds were surface-sterilised by dipping them in diluted bleach (1\% v: v) for 1 min and thoroughly rinsing them with sterile distilled water. Seeds were initially sown in sterilised potting soil (John Innes No. 2, Westland Garden Health, UK), germinated in a greenhouse and grown for four weeks, receiving water daily. The seedlings were then transplanted into pots and, after one week, dead plants were replaced, and Nfertiliser was applied. Each mesocosm pot contained a total of 12 plants. Pots were maintained in a controlled environment room (temperature, $19^{\circ} \mathrm{C}$ day, $16^{\circ} \mathrm{C}$ night; light between 08:00 $\mathrm{h}$ and 20:00 $\mathrm{h}$ daily).

Greenhouse gas fluxes measurements

Measurements of $\mathrm{CO}_{2}, \mathrm{~N}_{2} \mathrm{O}$ and $\mathrm{CH}_{4}$ were made on mesocosm pots using opaque plastic chambers $(13 \mathrm{~cm}$ diameter and $12 \mathrm{~cm}$ depth) with septa to allow headspace gas sampling. For each gas flux measurement, the chamber was attached with clip seal to the mesocosm and a $10 \mathrm{~mL}$ headspace sample was taken immediately (t0) with a gas syringe. $5 \mathrm{~mL}$ of the gas was then injected into a pre-evacuated $3.5 \mathrm{~mL}$ exetainer vial (Labco, Lampeter, UK). Further headspace samples were taken 15 (t15) and 30 (t30) minutes after chamber closure. Chambers were then removed. Gas samples were analysed using a PerkinElmer Autosystem XL Gas Chromatograph (GC) (PerkinElmer, Waltham, MA, USA) fitted with a methaniser with a Flame Ionisation Detector (FID) and Electron Capture Detector (ECD) operating at $130^{\circ} \mathrm{C}$. The GC was fitted with a stainless steel Porapak Q 50-80 mesh column (length $2 \mathrm{~m}$, outer diameter $3.17 \mathrm{~mm}$ ) maintained at $60{ }^{\circ} \mathrm{C}$. Three calibration gas standards $(500 \mathrm{ppm}, 1000 \mathrm{ppm}, 4000 \mathrm{ppm}$ $\mathrm{CO}_{2}$ ) (Air Products, Waltham on Thames, UK) were run every 14 samples to enable calibration and drift correction (Case et al. 2012). Gas fluxes were calculated using linear regressions through sampling time points and were corrected for temperature and barometric pressure following the ideal gas law (Holland et al. 1999). 
Gases were sampled immediately after $\mathrm{N}$ application and daily during the first 14 days of the experiment, then three times a week up to day 40. Cumulative GHG fluxes were calculated by linear interpolation of the average GHG emissions between the measurements to integrate the fluxes over the total experimental period. Emissions of $\mathrm{N}_{2} \mathrm{O}$ and $\mathrm{CH}_{4}$ were converted to use the concept of global warming potential (GWP) (IPCC 2007), where the GWP value for $\mathrm{CH}_{4}$ (based on a 100 -yr time horizon) is 34 and for $\mathrm{N}_{2} \mathrm{O}$ is 298 (IPCC 2013). The net GHG balance was calculated by the mean of GHG $\left(\mathrm{N}_{2} \mathrm{O}\right.$ and $\left.\mathrm{CH}_{4}\right)$ and soil carbon stock (SOC) (Table 5).

\section{Plant and soil analyses}

At the end of the experiment (40 days), grass and legume above-ground biomass were harvested and separated, with dry matter content determined by drying in an oven at $105^{\circ} \mathrm{C}$ for $24 \mathrm{~h}$. Subsamples were dried at $60{ }^{\circ} \mathrm{C}$ for $24 \mathrm{~h}$, then ground and analysed for total $\mathrm{C}$ and $\mathrm{N}$ content using an elemental analyser (TruSpec ${ }^{\circ} \mathrm{CN}$, St. Joseph, MI) with a furnace temperature of $950{ }^{\circ} \mathrm{C}$. Ethylenediaminetetraacetic acid (EDTA) was used as a reference. To determine shoot $\mathrm{N}$ uptake per plot, values of shoot $\mathrm{N}$ content (\%) were multiplied by total dry matter content which is the shoot $\mathrm{N}$ content at the end of the experiment.

Soil was taken from the pots at the end of the experimental period. Gravimetric moisture content was determined after drying at $105^{\circ} \mathrm{C}$ for $24 \mathrm{~h}$. Mineral-N $\left(\mathrm{NH}_{4}{ }^{+}\right.$ and $\mathrm{NO}_{3}{ }^{-}$) was extracted with $1 \mathrm{M} \mathrm{KCl}$ in a $1: 5$ (soil weight: extractant volume) ratio and analysed with a spectrophotometer (Auto Analyser 3 Digital colorimeter BRAN + LUBBE). Net mineralisation (net $\mathrm{N}$ production: $\mathrm{NH}_{4}{ }^{+}-\mathrm{N}+\mathrm{NO}_{3}{ }^{-}-\mathrm{N}$ ) and net nitrification (net $\mathrm{NO}_{3}{ }^{-}-\mathrm{N}$ production) rate were determined by incubating the soil at $25^{\circ} \mathrm{C}$ for 14 days, analysing the final mineral-N content as described above, then calculating the daily mineral-N production rate as the difference between final and initial inorganic $\mathrm{N}$ content, divided by the incubation period. Soil $\mathrm{C}$ and $\mathrm{N}$ were determined after dried subsamples at $60{ }^{\circ} \mathrm{C}$ at $24 \mathrm{~h}$, then finely ground using an elemental analyser (TruSpec $® \mathrm{CN}$, St. Joseph, MI) with furnace temperature at $950{ }^{\circ} \mathrm{C}$. Soil $\mathrm{pH}$ was measured on $10 \mathrm{~g}$ fresh soil with $25 \mathrm{~mL}$ deionised water, left to stand for $30 \mathrm{~min}$ and then tested with $210 \mathrm{pH}$ Meter (Hanna Instruments, RI, USA). Plant roots were separated from the soil from each mesocosm pot to determine below-ground biomass/productivity after washing and drying at $105{ }^{\circ} \mathrm{C}$ for $24 \mathrm{~h}$. A subset of roots was stored in the fridge with $10 \%$ ethanol solution to measure specific root length (SRL) and root dry matter content (RDMC). Root length and diameter were analysed using WinRhizo® root analysis software (Regent Instruments Inc., Sainte-Foy-Sillery-CapRouge, QC, Canada) coupled to an Epson flatbed scanner.

\section{Statistical analyses}

Generalised least squares models (GLS) were used to test the significance of treatment effects on plant productivity, plant-soil properties and GHG emissions. As most variables did not fit a linear regression, quadratic and cubic regressions were included in the model with the following formulae, where LEG refers to legume proportion and NADD to $\mathrm{N}$ addition:

$$
\begin{aligned}
& \mathrm{y} \sim \mathrm{LEG} * \mathrm{NADD}+\mathrm{I}\left(\mathrm{LEG}^{2}\right) * \mathrm{NADD} \\
& +\mathrm{I}\left(\mathrm{LEG}^{3}\right) * \mathrm{NADD}
\end{aligned}
$$

Fixed effects were LEG, $\mathrm{LEG}^{\wedge} 2$, $\mathrm{LEG}^{\wedge} 3$, NADD and their interactions. For all GLS models, data were checked for normality and equal variances using residual plots method, and log-transformed where necessary before analysis (i.e. for cumulative $\mathrm{CO}_{2}$, below-ground biomass, shoot $\mathrm{N}$ yield, shoot $\mathrm{C}: \mathrm{N}$, shoot:root ratio, soil mineral-N, $\mathrm{N}$ mineralisation and nitrification). Weight functions were used to account for unequal variances following (Zuur et al. 2009). The same model parameters were found to be significant when legume proportion (\%) was replaced with legume biomass. The proportion of legumes and biomass legumes were very highly correlated $\left(r^{2}=0.80\right.$, Variance inflation factors (VIF) $>$ 5). Additionally, the model with legume proportion showed the lowest Akaike information criterion (AIC). Tukey post hoc testing was performed to test the effects between grass-legume mixtures and monocultures using a pairwise comparison between different legumes proportions. All statistical analysis and graphs were made using R programming language 3.4.3 (R Development Core Team 2017) with the additional packages nlme (Pinheiro et al. 2019), plyr (Wickham 2011) and multcomp (Hothorn et al. 2008). 


\section{Results}

Realised legume proportion

The objective of this study was to achieve grass-legume mixtures with $25 \%, 50 \%$ and $75 \%$ legume abundance, based on percentage calculated as number of plants. However, at the end of the experiment, the realised legumes achieved was 38\%, $45 \%$ and $53 \%$ for unfertilised soils and $32 \%, 36 \%$ and $41 \%$ for fertilised soils based on legumes biomass (g dwt) (Fig. 1). This shows that legume plant weight was not largely different between treatments.

\section{Plant productivity}

There was a significant, non-linear relationship between the proportion of legumes and above-ground biomass in the unfertilised and fertilised soil ( $p=$ $0.02, \mathrm{LEG}^{2} * \mathrm{NADD}$, Fig. 2a, Table 1) showing that above-ground biomass was greater in fertilised compared to unfertilised soils in all treatments except for the legume monoculture (100\%). Below-ground biomass decreased non-linearly with increases in legume proportion in both unfertilised and fertilised soil, with a significant interaction between legume and fertiliser treatments $\left(p=0.03, \mathrm{LEG}^{3} * \mathrm{NADD}\right.$, Fig. $2 \mathrm{~b}$, Table 1). In unfertilised soils, below-ground biomass increased between 0 and $25 \%$ legume treatments and then decreased with subsequent increases in legume proportions (Table S2). In contrast, in the fertilised soils, below-ground biomass was consistent in the three mixture treatments $(25 \%, 50 \%$, $75 \%$ ), and was smaller than the grass monoculture and greater than the legume monoculture (Table S2).

Shoot $\mathrm{N}$ uptake ( $\mathrm{g} \mathrm{N} \mathrm{m}^{-2}$, total $\mathrm{N}$ in grass+legumes) had a significant non-linear relationship with legume proportion $(p<0.0001$, LEG*NADD, Table 2$)$, with greater shoot $\mathrm{N}$ uptake in fertilised compared to unfertilised soil (Fig. 3a). In unfertilised and fertilised soils, shoot $\mathrm{N}$ uptake is greater in the grass-legume mixtures than in the monocultures (Table S2), and this reflects the differences found in above-ground biomass which is also greater in the mixtures soils (Fig. 2a).

The shoot $\mathrm{N}$ concentration (\%) of the grasses and legumes decreased linearly with increases in legume proportion in the fertilised soils, but not in unfertilised soils ( $p=0.03$ and $p=0.001$, LEG ${ }^{*}$ NADD, in grass and legume species respectively, Fig. $3 b$, c, Table 2). The shoot $\mathrm{N}$ concentration (\%) in grass and legumes was greater in fertilised compared to unfertilised soil. Shoot $\mathrm{CN}$ ratio decreased with increases in legume proportion $\left(p<0.0001\right.$, LeG $^{*}$ NADD, Fig. 3d, Table 2$)$, only in unfertilised soil, while shoot/root ratio increased with increasing legume proportion in unfertilised soils $(p=$ 0.01, LeG* NADD, Fig. 3e, Table 2).

Soil parameters

Soil $\mathrm{pH}$ was not affected by increases in legume proportion $(p>0.05$, Table 3$)$ but was significantly decreased by $\mathrm{N}$ addition from an average of 6.1 to $5.4(p<0.05$, Table 3). Total soil $\mathrm{N}, \mathrm{NO}_{3}{ }^{-}-\mathrm{N}$ and net nitrification rates were not significantly affected by legume proportion $(p>0.05$, Table 3$)$, but were greater under $\mathrm{N}$ addition $\left(\mathrm{p}<0.05\right.$, Table 3). Soil $\mathrm{NH}_{4}{ }^{+}-\mathrm{N}$ had a non-linear relationship with increasing legume proportion $(p=$ 0.001 , LEG ${ }^{2} *$ NADD, Table 3 ) but only in fertilised treatments. Net mineralisation rate increased nonlinearly with increases in legume proportions $(p=$ 0.006, LEG $^{3} *$ NADD, Table 3 ), on the fertilised soils only. Some treatments are not described in Table 3 as they are not showing any significant effects (i.e. LEG $x$ NADD, $\mathrm{LEG}^{2}, \mathrm{LEG}^{3}$ ).

Greenhouse gas fluxes

Increased legume proportion did not affect cumulative $\mathrm{N}_{2} \mathrm{O}$ emissions, regardless of $\mathrm{N}$ addition $(\mathrm{p}>0.05$, Fig. 4a, Table 4). N-fertiliser addition stimulated $\mathrm{N}_{2} \mathrm{O}$ emissions by approximately four times compared to unfertilised soils $(p<0.0001$, Fig. 4a, Table 5). Cumulative $\mathrm{CO}_{2}$ fluxes (ecosystem respiration) decreased with increasing legume proportion $(\mathrm{p}<0.0001$, LEG*NADD, Fig. 4b, Table 5) in fertilised soils, but were consistent in unfertilised soils. Cumulative $\mathrm{CH}_{4}$ emissions were affected by legume proportion with a significant cubic regression $(p=0.01$, Table 5), which means that there were significant differences between treatments but no consistent trend with increasing legume proportion. In unfertilised soils, $\mathrm{CH}_{4}$ emissions were greater with $25 \%$ of legumes than $50 \%$ of legumes, while in fertilised soil $25 \%$ of legumes $\mathrm{CH}_{4}$ fluxes were greater with than $75 \%$ of legumes (Table $\mathrm{S} 2$ ). $\mathrm{N}$ addition significantly increased $\mathrm{CH}_{4}$ emissions by up to 50 times compared to unfertilised soils $(\mathrm{p}<0.0001$, Fig. $4 \mathrm{c})$. 
Fig. 1 Legume above-ground biomass $\left(\mathrm{g} \mathrm{dwt} \mathrm{m}^{-2}\right)$ within grasslegume mixtures at the end of the controlled temperature mesocosm experiment. Percentage above bars represent realised legume proportion. Data represent mean $\pm \mathrm{SE}(n=5)$

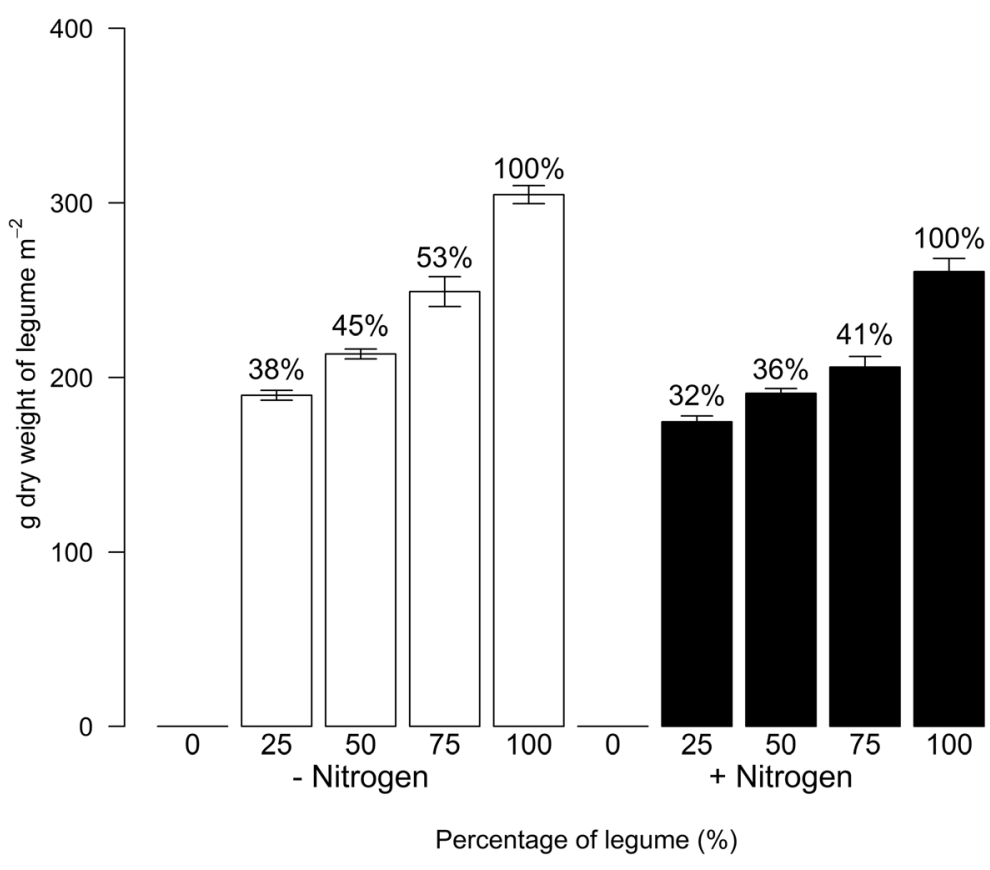

\section{Discussion}

The aim of this study was to investigate how grassland legume proportion and $\mathrm{N}$ addition interact to affect plant-soil properties with feedback consequences for ecosystem GHG emissions. Legume proportions in grass-legume mixtures increased total plant productivity although there was no effect on ecosystem respiration or $\mathrm{N}_{2} \mathrm{O}$ emissions from the soil. Greater GHG emission differences were observed between unfertilised and fertilised soils. Below, we will discuss the effect of grass-legume mixtures on plant productivcity and shoot
Fig. 2 Total above- (a) and below-ground (b) biomass ( $\mathrm{g}$ dwt $\mathrm{m}^{-2}$ ) in response to legume proportion and nitrogen addition treatments after six weeks growth under controlled environment conditions. Data represent mean $\pm \mathrm{SE}(\mathrm{n}=5)$
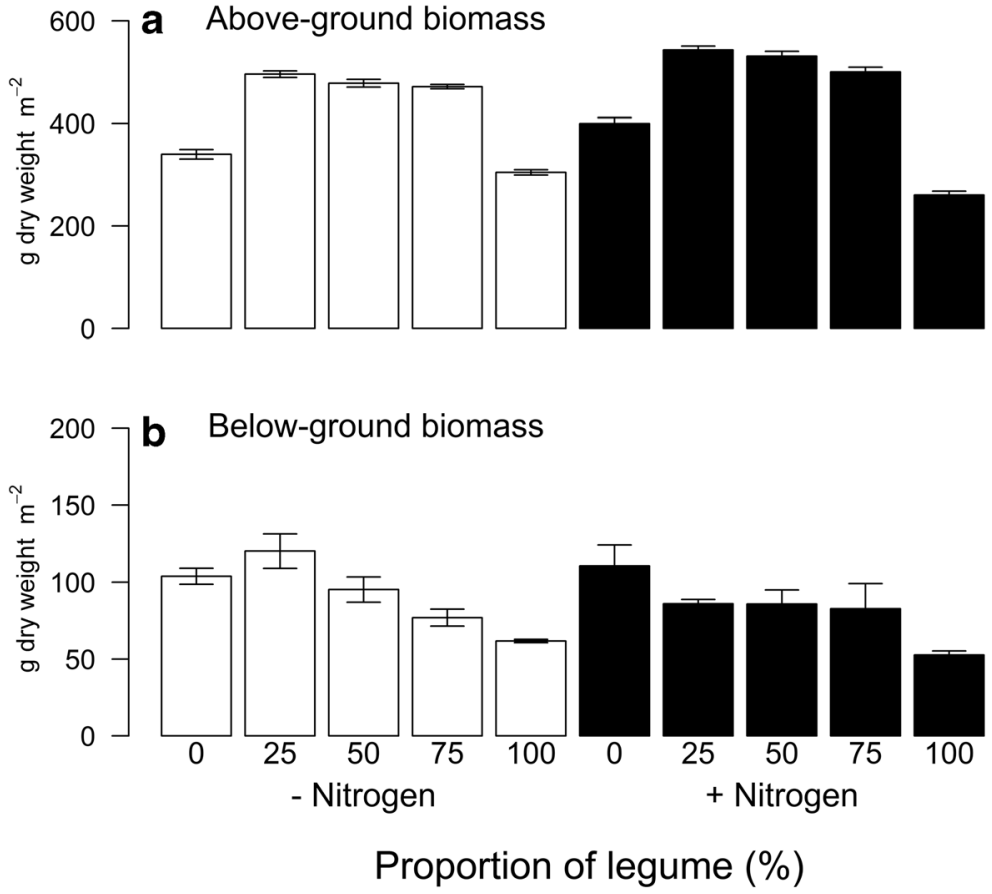
Table 1 The effect of legume proportion (LEG), nitrogen addition (NADD) and interactions on above- and below-ground biomass

\begin{tabular}{|c|c|c|c|c|c|}
\hline & \multirow[t]{2}{*}{ d.f. } & \multicolumn{2}{|c|}{ Above-ground biomass $g$ dry weight $\mathrm{m}^{-2}$} & \multicolumn{2}{|c|}{ Below-ground biomass $g$ dry weight $\mathrm{m}^{-2}$} \\
\hline & & $\mathrm{F}$ value & $P$ & $\mathrm{~F}$ value & $P$ \\
\hline LEG linear (LEG) & 1 & 61.70 & $<0.0001$ & 58.96 & $<0.0001$ \\
\hline NADD & 1 & 14.93 & 0.0004 & 3.77 & 0.06 \\
\hline LEG quadratic $\left(\mathrm{LEG}^{2}\right)$ & 1 & 511.44 & $<0.0001$ & 5.19 & 0.03 \\
\hline LEG cubic $\left(\operatorname{LEG}^{3}\right)$ & 1 & 0.57 & 0.45 & 0.15 & 0.70 \\
\hline LEG $x$ NADD & 1 & 18.29 & 0.0001 & 0.03 & 0.85 \\
\hline LEG $^{2} x$ NADD & 1 & 5.77 & 0.02 & 0.37 & 0.54 \\
\hline $\mathrm{LEG}^{3} x$ NADD & 1 & 1.60 & 0.21 & 4.97 & 0.03 \\
\hline
\end{tabular}

Above-ground biomass corresponds to the legume+grass biomass. Significant effects $(P<0.05)$ are shown in bold

$\mathrm{N}$ uptake, and how legume proportions affect GHG emissions in the presence or absence of $\mathrm{N}$, linking them with plant productivity and plant-soil properties.

Effect of grass-legumes mixtures and $\mathrm{N}$ addition on plant productivity and shoot $\mathrm{N}$ uptake

According to our hypothesis, in unfertilised soils increasing legumes would increase productivity overall, but our second hypothesis states that grasses would be favoured over legumes in fertilised soils. Interestingly, our results showed that grass-legumes mixtures had higher plant productivity (above-ground biomass) compared to monocultures in both fertilised and unfertilised soils regardless of the proportion of legumes, but in fertilised soils, mixtures showed greater productivity (Fig. 2). Shoot $\mathrm{N}$ uptake followed the same pattern (Fig. 3a), indicating that the presence of legumes in mixtures facilitates increased $\mathrm{N}$ uptake and therefore increased plants growth.

The increase in plant productivity in grass-legume mixtures can be explained due to the ability of legumes to fix atmospheric $\mathrm{N}_{2}$ in the soil providing $\mathrm{N}$ rich organic matter (Mulder et al. 2002; Spehn et al. 2002). Leguminous species can then significantly affect grassland biomass production (Spehn et al. 2000) and produce three times greater biomass compared to mixtures without legumes (Spehn et al. 2000). Legumes in grasslegume mixtures in this study have contributed to an increase of $40-60 \%$ plant productivity. In addition to $\mathrm{N}_{2}$ fixation, legumes can increase plant productivity in mixed communities by spatial or temporal complementarity of soil resource use. For instance, grasses and legumes have different root morphology, which may be responsible for different strategies of resources use (Table S1). Clovers (Trifolium spp) have thicker, shorter,

Table 2 Effects of legume proportion (LEG), nitrogen addition (NADD) and interaction on shoot N uptake, grass and legume N content, shoot $\mathrm{CN}$ ratio and shoot/root ratio

\begin{tabular}{|c|c|c|c|c|c|c|c|c|c|c|c|}
\hline & \multirow[t]{2}{*}{ d.f. } & \multicolumn{2}{|c|}{$\begin{array}{l}\text { Shoot } \mathrm{N} \text { uptake } \\
\left(\mathrm{g} \mathrm{m}^{-2}\right)\end{array}$} & \multicolumn{2}{|c|}{$\begin{array}{l}\text { Grass N content } \\
(\%)\end{array}$} & \multicolumn{2}{|c|}{$\begin{array}{l}\text { Legume N content } \\
(\%)\end{array}$} & \multicolumn{2}{|c|}{ Shoot $\mathrm{CN}$ ratio } & \multicolumn{2}{|c|}{$\begin{array}{l}\text { Shoot/Root biomass } \\
\text { ratio }\end{array}$} \\
\hline & & $\mathrm{F}$ value & $P$ & $\mathrm{~F}$ value & $P$ & $\mathrm{~F}$ value & $P$ & F value & $P$ & F value & $P$ \\
\hline LEG linear (LEG) & 1 & 21.04 & $<0.0001$ & 1.10 & 0.30 & 0.21 & 0.65 & 8.35 & 0.006 & 14.0 & 0.0005 \\
\hline NADD & 1 & 1401.12 & $<0.0001$ & 2238.94 & $<0.0001$ & 1124.8 & $<0.0001$ & 1948.7 & $<0.0001$ & 4.12 & 0.05 \\
\hline LEG quadratic $\left(\mathrm{LEG}^{2}\right)$ & 1 & 307.83 & $<0.0001$ & 0.10 & 0.76 & 0.70 & 0.41 & 0.84 & 0.36 & 32.75 & $<0.0001$ \\
\hline LEG cubic $\left(\operatorname{LEG}^{3}\right)$ & 1 & 12.53 & 0.001 & 0.50 & 0.48 & 0.02 & 0.88 & 1.72 & 0.20 & 0.47 & 0.50 \\
\hline LEG x NADD & 1 & 70.77 & $<0.0001$ & 5.30 & 0.03 & 12.94 & 0.001 & 36.95 & $<0.0001$ & 6.41 & 0.01 \\
\hline LEG $^{2}$ x NADD & 1 & 8.17 & 0.007 & 0.17 & 0.68 & 0.01 & 0.91 & 0.00 & 0.99 & 1.94 & 0.17 \\
\hline LEG $^{3} x$ NADD & 1 & 1.87 & 0.18 & 0.04 & 0.85 & 0.55 & 0.46 & 0.33 & 0.57 & 1.22 & 0.14 \\
\hline
\end{tabular}

Significant effects $(P<0.05)$ are shown in bold 

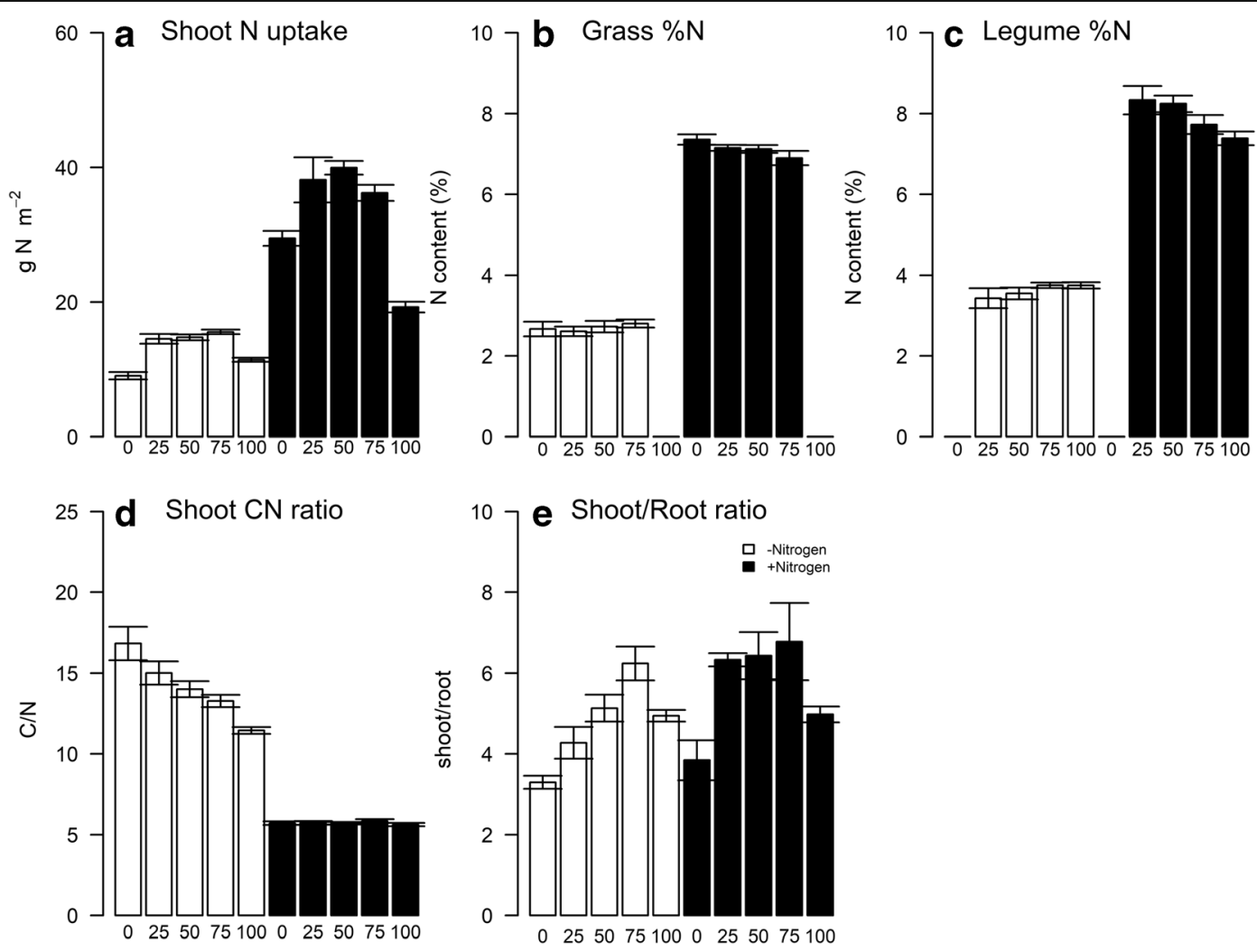

Proportion of legume (\%)

Fig. 3 Interactive effects of legume proportion and nitrogen addition on a) total shoot $\mathrm{N}$ uptake $\left(\mathrm{g} \mathrm{N} \mathrm{m}^{-2}\right)$, b) Grass $\mathrm{N}$ content $(\%)$, c) Legume $\mathrm{N}$ content (\%), d) shoot $\mathrm{CN}$ ratio, and e) shoot/root

and less branched root systems (Haynes 1980) i.e. lower SRL, and exhibit weak competition for nutrients with low mobility in the soil. While grasses (Agrostis spp) are more soil exploitative species, which invest more energy in the development of roots to acquire nutrients from the soil (De Deyn et al. 2008; Maire et al. 2009). Increased productivity of mixtures may, therefore, be due to different species functional traits and complementarity in resource use. This might also increase $\mathrm{N}$ use efficiency (van Ruijven and Berendse 2005) and facilitate $\mathrm{N}$ transfer from legumes to grasses (Høgh-Jensen and Schjoerring 1997; Laidlaw et al. 1996). In unfertilised soils, shoot $\mathrm{CN}$ ratio declined with increases in legume proportion (Fig. 3a), showing that mixtures with legumes are acquiring more $\mathrm{N}$ and increasing $\mathrm{N}$ use efficiency of the sward.

The increase of $\mathrm{N}$ transfer from legumes to grasses (McElroy et al. 2017) is another important process that can promote greater productivity. As shown by the $\mathrm{N}$ ratio (dwt biomass) after six weeks growth under controlled environment conditions. Data represent mean $\pm \operatorname{SE}(n=5)$

concentration in the grass in monoculture and mixtures, $\mathrm{N}$ transfer to grasses from legumes in mixtures was not significantly different (Fig. 3b, c), however shoot $\mathrm{N}$ uptake was higher in mixtures compared to monoculture indicating that when legumes are present, companion plants can access more nutrients. Grassland field experiments suggest the benefits of legumes to overall plant productivity are evident at around 30-50\% of realised legume proportion based on above-ground biomass (Suter et al. 2015). This corresponds well with our findings, where legume proportions between 25 and $75 \%$ (which correspond to $33-50 \%$ realised legume proportion based on above-ground biomass at the end of the experiment) showed higher above-ground productivity and shoot $\mathrm{N}$ uptake, and were significantly greater than either grass or legume monocultures in both unfertilised and fertilised soils (Fig. 2a, b, 3a). There were no significant differences in productivity between the three mixture treatments, which is explained by 

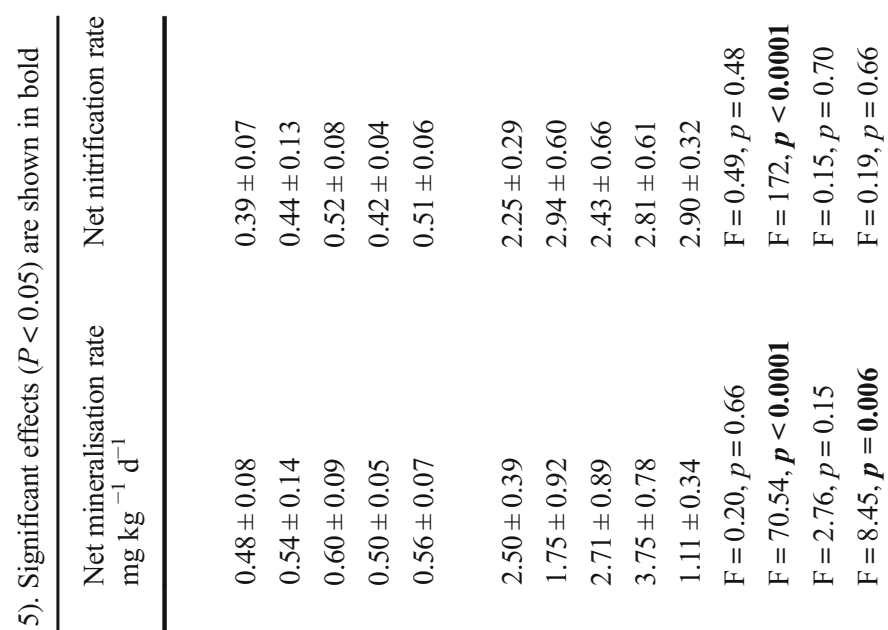

क ఫ

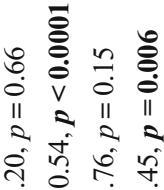

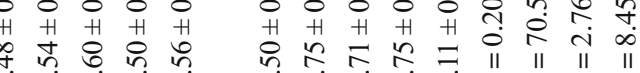

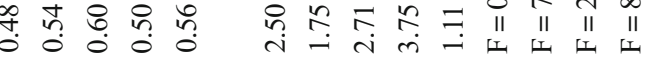

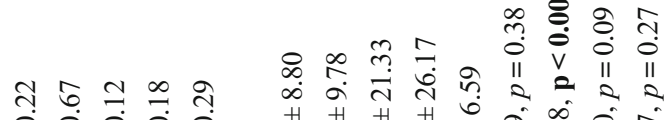

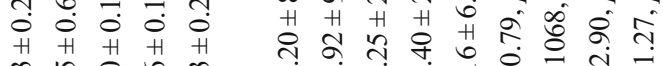

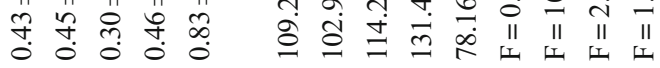

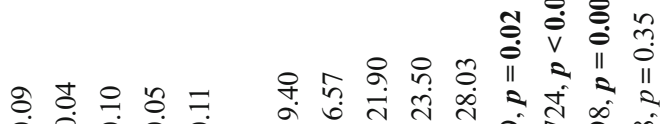
H H $\begin{aligned} & H \\ & \text { H }\end{aligned}$

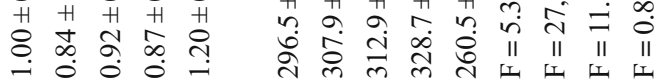

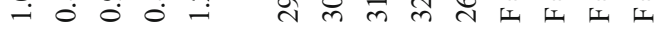

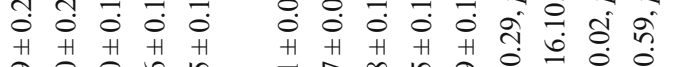
然

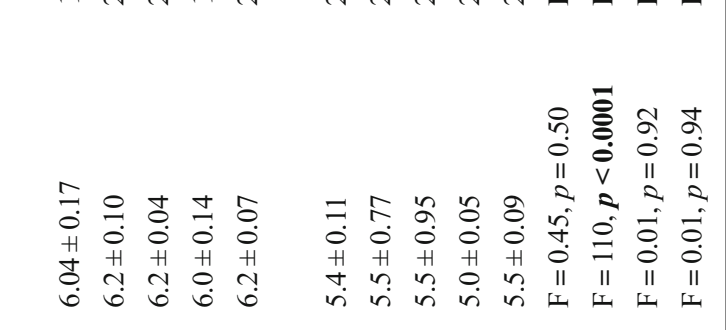
$\frac{\pi}{2}$ 


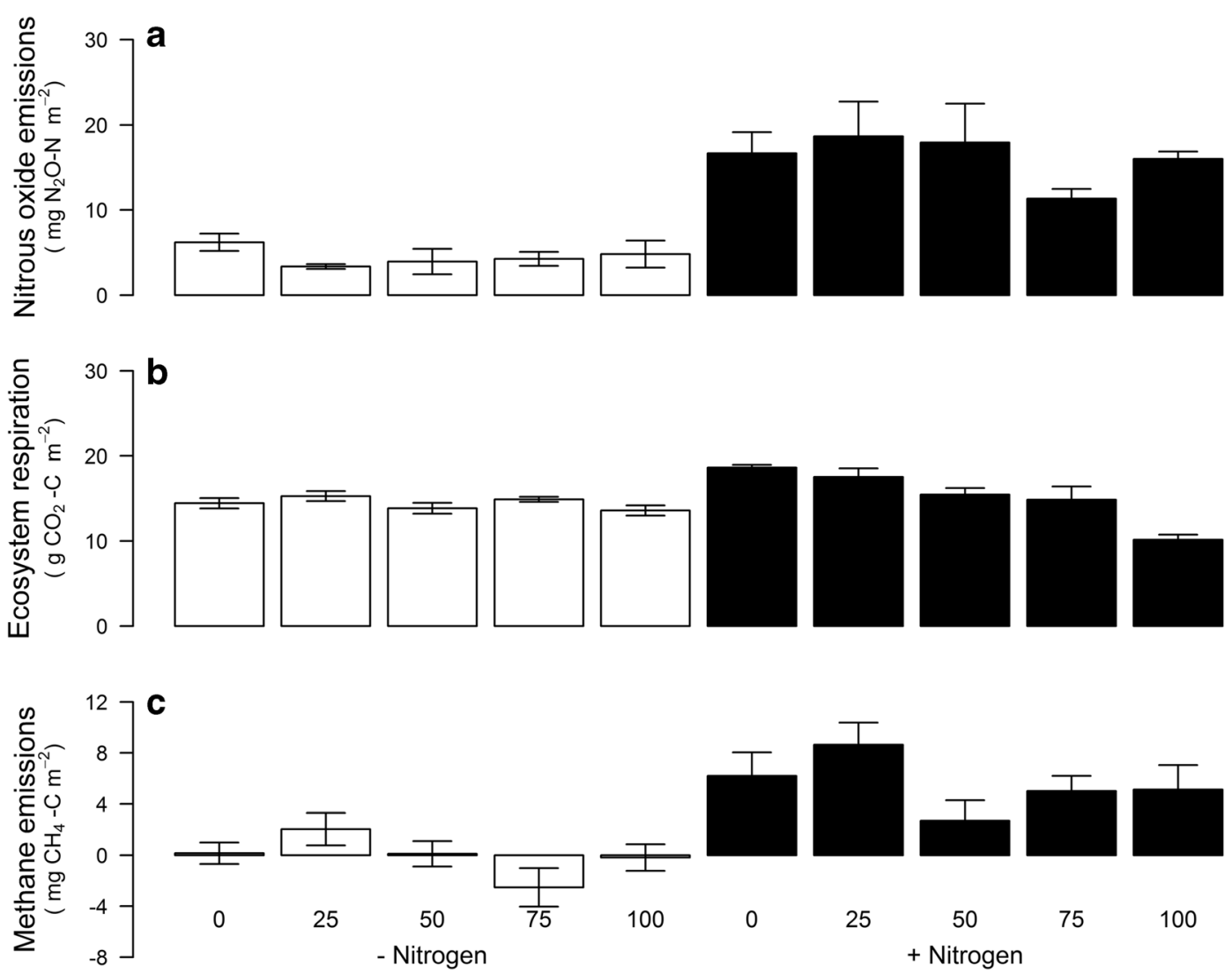

\section{Proportion of legume (\%)}

Fig. 4 Cumulative $\mathrm{N}_{2} \mathrm{O}\left(\mathrm{mg} \mathrm{N}_{2} \mathrm{O}-\mathrm{N} \mathrm{m}^{-2}\right)$ (a), $\mathrm{CO}_{2}\left(\mathrm{~g} \mathrm{CO}_{2}-\mathrm{C} \mathrm{m}^{-2}\right)$ (b) and $\mathrm{CH}_{4}\left(\mathrm{mg} \mathrm{CH}_{4}-\mathrm{C} \mathrm{m}^{-2}\right)$ (c) emissions in response to legume proportion and nitrogen addition in the controlled temperature

similar realised legume proportions (Fig. 1). As a result our study was unable to determine the legume proportion which would maximise plant productivity and mesocosm experiment. Data are mean of cumulative emissions for all sampling dates $\pm \operatorname{SE}(n=18)$

mitigate $\mathrm{N}_{2} \mathrm{O}$ emissions. Studies have found that oversowing clover without any fertilisation compared to low clover proportion with organic fertilisation reduced $\mathrm{N}_{2} \mathrm{O}$

Table 4 Effects of legume proportion (LEG) and nitrogen addition (NADD) on cumulative emissions of $\mathrm{N}_{2} \mathrm{O}, \mathrm{CO}_{2}, \mathrm{CH}_{4}$

\begin{tabular}{|c|c|c|c|c|c|c|c|}
\hline & \multirow[t]{2}{*}{ d.f. } & \multicolumn{2}{|c|}{$\mathrm{N}_{2} \mathrm{O}$ emissions $\mathrm{mg} \mathrm{N}_{2} \mathrm{O}-\mathrm{N} \mathrm{m}^{-2}$} & \multicolumn{2}{|c|}{$\mathrm{CO}_{2}$ emissions $\mathrm{g} \mathrm{CO}_{2}-\mathrm{C} \mathrm{m}^{-2}$} & \multicolumn{2}{|c|}{$\mathrm{CH}_{4}$ emissions $\mathrm{mg} \mathrm{CH}-\mathrm{C} \mathrm{m}^{-2}$} \\
\hline & & $\mathrm{F}$ value & $P$ & $\mathrm{~F}$ value & $P$ & $\mathrm{~F}$ value & $P$ \\
\hline LEG linear (LEG) & 1 & 0.93 & 0.34 & 21.3 & $<0.0001$ & 3.19 & 0.08 \\
\hline NADD & 1 & 65.22 & $<0.0001$ & 1.1 & 0.30 & 35.54 & $<0.0001$ \\
\hline LEG quadratic $\left(\mathrm{LEG}^{2}\right)$ & 1 & 1.81 & 0.18 & 3.4 & 0.07 & 0.11 & 0.74 \\
\hline LEG cubic $\left(\mathrm{LEG}^{3}\right)$ & 1 & 0.03 & 0.86 & 0.6 & 0.45 & 7.12 & 0.01 \\
\hline LEG $x$ NADD & 1 & 0.43 & 0.52 & 26.2 & $<0.0001$ & 0.006 & 0.94 \\
\hline $\operatorname{LEG}^{2} \times$ NADD & 1 & 0.33 & 0.57 & 1.9 & 0.17 & 0.18 & 0.67 \\
\hline $\mathrm{LEG}^{3} \mathrm{x}$ NADD & 1 & 2.83 & 0.10 & 0.9 & 0.35 & 0.15 & 0.69 \\
\hline
\end{tabular}

Significant effects $(P<0.05)$ are shown in bold 
Table 5 Net GHG balance for each grass-legume mixture without and with $\mathrm{N}$ fertilisation

\begin{tabular}{ll}
\hline Treatments & $\begin{array}{l}\text { Net GHG balance } \\
\mathrm{g} \mathrm{CO}_{2} e q \mathrm{~m}^{-2}\end{array}$ \\
\hline Without N & \\
$0 \%$ Legume & 27.7 \\
25\% Legume & 27.8 \\
$50 \%$ Legume & 30.6 \\
$75 \%$ Legume & 26.8 \\
100\% Legume & 31.6 \\
With N & \\
$0 \%$ Legume & 33.8 \\
$25 \%$ Legume & 35.8 \\
$50 \%$ Legume & 33.2 \\
$75 \%$ Legume & 32.8 \\
$100 \%$ Legume & 33.6 \\
\hline
\end{tabular}

Net GHG balance was calculate by the mean of GHG $\left(\mathrm{N}_{2} \mathrm{O}, \mathrm{CH}_{4}\right.$ emissions) and soil carbon stock

emissions by $54 \%$ and $39 \%$ in year 1 and 2 of a field experiment (Fuchs et al. 2018). However, this reduction in emissions is more likely to be related to the difference in fertilisation between treatments rather than clover proportions per se. A study from Migliorati et al. (2015) found a 50\% reduction in $\mathrm{N}_{2} \mathrm{O}$ emissions from soil which had sorghum grown in legume history compared to sorghum grown in grass crop history without affecting plant productivity. This shows the importance of determining the optimum amount of legume needed in mixtures without compromising plant productivity and the environment.

Effects of legume proportion on GHG emissions in unfertilised soils

In unfertilised soils, despite the increase in plant productivity and total shoot $\mathrm{N}$ uptake with increasing legume proportion, below-ground biomass was reduced at higher legume proportions and there was no significant effect of legume proportion on ecosystem respiration or $\mathrm{N}_{2} \mathrm{O}$ emissions but there was a significant effect on $\mathrm{CH}_{4}$ emissions. $\mathrm{N}_{2} \mathrm{O}$ emissions may have been unaffected under $\mathrm{N}$-limiting conditions, as it has been suggested that the flux rate through $\mathrm{N}$ pools (Jones et al. 2005) is more important than the actual size of the relative $\mathrm{N}$ pools. Fast-growing species such as T. pratense and A. capillaris increase $\mathrm{N}$ mineralisation (Fig. $\mathrm{S} 1$ ) from soil organic matter to a greater extent than more conservative species, with consequent increases in their growth (Personeni and Loiseau 2005; Van Der Krift and Berendse 2001). This higher $\mathrm{N}$ availability may temporarily enhance $\mathrm{N}_{2} \mathrm{O}$ emissions, given that soil microbes such as nitrifiers and denitrifiers are good competitors for both $\mathrm{NH}_{4}{ }^{+}$and $\mathrm{NO}_{3}{ }^{-}$(Hodge et al. 2000). However, as found in many studies, the rate of net $\mathrm{N}$ uptake is four- to six-fold higher for faster growing species compared to slower growing plant species (Poorter et al. 1991). This fast flux between soil $\mathrm{N}$ supply and $\mathrm{N}$ use by both plants and microorganisms (Jackson et al. 1989) would result in no build-up of a soil mineral-N pool (Abalos et al. 2014), and would explain the decoupling between biomass production and $\mathrm{N}_{2} \mathrm{O}$ emissions. As a consequence, under $\mathrm{N}$-limiting conditions, the acceleration of the $\mathrm{N}$ cycle caused by these two fast-growing species (Orwin et al. 2010) is likely to offset the production-induced reduction in $\mathrm{N}_{2} \mathrm{O}$ emissions that we hypothesised. In this context, the presence of these two fast-growing species might increase the input of $\mathrm{C}$ and $\mathrm{N}$ root exudates especially from legumes, which typically stimulate the growth of soil microbes (Denton et al. 1998; Mawdsley and Bardgett 1997). Increases in microbial biomass may have increased microbial respiration and offset the decrease in ecosystem respiration, and therefore not be affected by increases in legume proportion (Fig. 4b).

Our results showed that grass-legume mixtures have increased above-ground biomass and decreased belowground biomass (Fig. 2). Legumes in N limiting conditions (i.e. with no $\mathrm{N}$-fertilisation) might have reduced root growth, potentially increasing specific root length (SRL); which is well-known to be increased in N limiting ecosystem. This increase in SRL is correlated with plant investment into structures structure to acquire $\mathrm{N}$ in the soil (Du et al. 2013; Ostonen et al. 2007) reducing Navailable thus reducing $\mathrm{N}_{2} \mathrm{O}$ emissions. Low $\mathrm{N}$ concentration may decrease root growth, providing a smaller sink for inorganic and legume-derived N (Ofosubudu et al. 1995; Paynel et al. 2008).

Increases in legume proportion affected $\mathrm{CH}_{4}$ uptake and emissions in both unfertilised and fertilised soils (Fig. 4c) but there was no consistent trend between legume proportion treatments (Fig. 4c). Many different and overlapping mechanisms might explain these effects. Species interactions might alter root densities and architecture, which may lead to changes in soil aeration, spatio-temporal organic $\mathrm{C}$ deposition, or $\mathrm{N}$ 
use pattern (Niklaus et al. 2016). These factors could contribute to the increased productivity of mixtures, augmenting the supply of organic substrates to the soil microbial community (Suwanwaree and Robertson 2005), and increasing oxygen consumption and soil diffusive conductance (Grosso et al. 2000; Smith et al. 2003). These will in turn change the biomass and activity of methanotrophs and methanogens in the soil, determining rates of net $\mathrm{CH}_{4}$ fluxes from soil (Ball et al. 1999).

Grass monocultures and grass-legumes mixtures in this study had higher soil $\mathrm{NH}_{4}{ }^{+}$concentrations compared to unfertilised legume monocultures (Table 3, Fig. S1). Unsurprisingly, this shows that $\mathrm{NH}_{4}{ }^{+}$concentration was strongly affected by $\mathrm{N}$-fertilisation. Although, in this study, it was possible to observe changes in $\mathrm{NH}_{4}{ }^{+}$concentration due to legume proportions, there was no clear correlation with $\mathrm{CH}_{4}$ uptake. Many studies suggest that $\mathrm{NH}_{4}{ }^{+}$may inhibit $\mathrm{CH}_{4}$ oxidation (Hütsch 1998; Rime and Niklaus 2017), due to competitive enzymatic process of methanotrophy and nitrification in soils (Baggs and Blum 2004). However $\mathrm{CH}_{4}$ oxidation may not be affect by $\mathrm{NH}_{4}{ }^{+}$if it is present in a different spatial niche to active methanotrophs (Hartmann et al. 2011). Therefore, this is most likely related to the interaction between grasses and legumes specifically and their impacts on $\mathrm{N}$ cycling. These results show that plant composition can affect $\mathrm{CH}_{4}$ fluxes, however, the short duration of the experiment, the low level of plant diversity and the lower realised legume proportion (Fig. 1) is likely to have contributed to the limited effects on $\mathrm{N}_{2} \mathrm{O}$ and $\mathrm{CO}_{2}$ emissions from the soil. Other experiments should be done to confirm the findings of this study in field conditions which will be important to evaluate the real effect of legume proportions on GHG emissions from soils.

Effects of legume proportion on GHG emissions in fertilised soils

In fertilised soils, agreeing with our hypothesis, $\mathrm{N}_{2} \mathrm{O}$ emissions were most affected by the mineral-N applied as $\mathrm{N}$-fertiliser, and its availability in the soil was irrespective of legume proportion in the sward. $\mathrm{N}_{2} \mathrm{O}$ emissions were not affected by increases in legume proportion, which can be largely explained by legume productivity. The presence of $\mathrm{N}$ in the system was a determining factor for a reduction and/or suppression of legume biomass (De Deyn et al. 2011; Smith et al. 2008), and probably to a decrease of $\mathrm{N}_{2}$ fixation (Ledgard et al. 2001). It may also affect the nodule production or induce a reduction of $\mathrm{N}$ fixation, which is shown, by the reduction of $\mathrm{N}$ concentration in legume species with increasing legume proportion (Naudin et al. 2010; Rasmussen et al. 2013). Different abiotic (e.g. water stress, microclimate temperature) and biotic (e.g. legume-grass plant density, root contact) factors may be changing ecosystem processes (Thilakarathna et al. 2016) that relate indirectly to $\mathrm{N}_{2} \mathrm{O}$ emissions.

In agreement with our hypothesis, ecosystem respiration was decreased by increases in legume proportion under non-N-limiting conditions. $\mathrm{N}$ addition might promote a reduction of legume biomass (favouring grasses) (McElroy et al. 2017), which may be the reason for the decrease in ecosystem respiration. Nyfeler et al. (2011) also showed that grasses benefited from $\mathrm{N}$ transfer from legumes in fertilised soil $\left(150 \mathrm{~kg} \mathrm{~N} \mathrm{ha}^{-1}\right)$. Additionally, some research suggests that root biomass is reduced in fertiliser treatments compared to unfertilised (Chirinda et al. 2012), due to higher root exploitation of soil to overcome the low nutrient availability in unfertilised soils. Although in our study root biomass was only slightly reduced in fertilised soil (Fig. 2). This reduction in root biomass might also decrease root respiration and overall ecosystem respiration. In addition, the reduction in ecosystem respiration may be related to less energy needed (especially by legumes) to acquire $\mathrm{N}$ in grasslegume mixtures (Drinkwater et al. 1998). Although we did not find a reduction in $\mathrm{N}_{2} \mathrm{O}$ emissions in this shortterm experiment, in the long-term including legumes and reducing $\mathrm{N}$-fertiliser inputs would result in a more closed efficient $\mathrm{N}$ cycle with environmental benefits. Other studies are needed to confirm the findings in this study, specifically regarding the interaction of legume proportion and $\mathrm{N}$ addition on the $\mathrm{N}$ cycle in grasslands and its potential effect on climate change.

Implications for grassland management and climate change

Incubation experiments offer a valuable means to investigate processes and mechanisms but need to be interpreted with caution as they cannot replicate field scale experiments. Furthermore, our observed effects may would be different as a function of soil type and moisture content. The use of the grass-legume mixture increased plant productivity in unfertilised and $\mathrm{N}$ fertilised soils without affecting nitrous oxide emissions. 
This raises a potential strategy to reduce $\mathrm{N}$-fertiliser use in the field, and an opportunity for climate change mitigation. The overall GHG budget calculated for this experiment showed that $\mathrm{N}$-fertilisation was the driver of increased GHG emissions independently of the mixtures (Table 5). Lower GHG emissions were found from soil which had $75 \%$ legumes grown in the grass-legumes mixtures without $\mathrm{N}$-fertiliser $\left(26.8 \mathrm{~g} \mathrm{CO}_{2} e q \mathrm{~m}^{-2}\right.$ ), followed by 0 and $25 \%$ (27.7 and $27.8 \mathrm{~g} \mathrm{CO}_{2} e q \mathrm{~m}^{-2}$, respectively) (Table 5). It will be important to evaluate the productivity legume-grass mixtures under field conditions, since legumes in excess could result in a reduction in plant productivity (Suter et al. 2015). Including legumes in grasslands may deliver the equivalent productivity as fertiliser, and although we did not find a reduction in $\mathrm{N}_{2} \mathrm{O}$ emissions in this short-term experiment, in the long-term the inclusion of legumes and reduced $\mathrm{N}$-fertiliser inputs would result in a more closed and efficient $\mathrm{N}$ cycle with environmental benefits.

Acknowledgements This study was supported by a grant to the first author from the Process 1263/2013-07 of the CAPES Foundation - Brazil (Science without Borders program). The authors thank Emma Eastoe for statistical advice.

Open Access This article is distributed under the terms of the Creative Commons Attribution 4.0 International License (http:// creativecommons.org/licenses/by/4.0/), which permits unrestricted use, distribution, and reproduction in any medium, provided you give appropriate credit to the original author(s) and the source, provide a link to the Creative Commons license, and indicate if changes were made.

\section{References}

Abalos D, De Deyn GB, Kuyper TW, Van Groenigen JW (2014) Plant species identity surpasses species richness as a key driver of $\mathrm{N}_{2} \mathrm{O}$ emissions from grassland global change. Biology 20:265-275. https://doi.org/10.1111/gcb.12350

Abalos D, van Groenigen JW, De Deyn GB (2018) What plant functional traits can reduce nitrous oxide emissions from intensively managed grasslands? Glob Chang Biol 24: e248-e258. https://doi.org/10.1111/gcb.13827

Avis EL, Harrop SE (1983) Sheet 1 northern England. Soils of England and Wales. Ordnance Survey, Southampton

Baggs EM, Blum H (2004) $\mathrm{CH}_{4}$ oxidation and emissions of $\mathrm{CH}_{4}$ and $\mathrm{N}_{2} \mathrm{O}$ from Lolium perenne swards under elevated atmospheric $\mathrm{CO}_{2}$ soil. Biol Biochem 36:713-723. https://doi. org/10.1016/j.soilbio.2004.01.008

Ball BC, Scott A, Parker JP (1999) Field $\mathrm{N}_{2} \mathrm{O}, \mathrm{CO}_{2}$ and $\mathrm{CH}_{4}$ fluxes in relation to tillage, compaction and soil quality in
Scotland. Soil Tillage Res 53:29-39. https://doi.org/10.1016 /S0167-1987(99)00074-4

Bardgett RD (2011) Plant-soil interactions in a changing world. F1000 Biol Rep 3:16. https://doi.org/10.3410/B3-16

Bardgett RD, Mawdsley JL, Edwards S, Hobbs PJ, Rodwell JS, Davies WJ (1999) Plant species and nitrogen effects on soil biological properties of temperate upland grasslands. Funct Ecol 13:650-660. https://doi.org/10.1046/j.13652435.1999.00362.x

Carter MS, Ambus P (2006) Biologically fixed $\mathrm{N}_{2}$ as a source for $\mathrm{N}_{2} \mathrm{O}$ production in a grass-clover mixture, measured by ${ }^{15} \mathrm{~N}_{2}$ nutrient. Cycling Agroecosyst 74:13-26. https://doi. org/10.1007/s10705-005-4111-0

Case SDC, McNamara NP, Reay DS, Whitaker J (2012) The effect of biochar addition on $\mathrm{N}_{2} \mathrm{O}$ and $\mathrm{CO}_{2}$ emissions from a sandy loam soil - the role of soil aeration. Soil Biol Biochem 51: 125-134. https://doi.org/10.1016/j.soilbio.2012.03.017

Chirinda N, Olesen JE, Porter JR (2012) Root carbon input in organic and inorganic fertilizer-based systems. Plant Soil 359:321-333. https://doi.org/10.1007/s11104-012-1208-5

Chistoserdova L, Vorholt JA, Lidstrom ME (2005) A genomic view of methane oxidation by aerobic bacteria and anaerobic archaea. Genome Biol 6:208. https://doi.org/10.1186/gb2005-6-2-208

De Deyn GB, Cornelissen JHC, Bardgett RD (2008) Plant functional traits and soil carbon sequestration in contrasting biomes. Ecol Lett 11:516-531. https://doi.org/10.1111/j.14610248.2008.01164.X

De Deyn GB, Quirk H, Yi Z, Oakley S, Ostle NJ, Bardgett RD (2009) Vegetation composition promotes carbon and nitrogen storage in model grassland communities of contrasting soil fertility. J Ecol 97:864-875. https://doi.org/10.1111 j.1365-2745.2009.01536.x

De Deyn GB et al (2011) Additional carbon sequestration benefits of grassland diversity restoration. J Appl Ecol 48:600-608. https://doi.org/10.1111/j.1365-2664.2010.01925.x

Denton CS, Bardgett RD, Cook R, Hobbs PJ (1998) Low amounts of root herbivory positively influence the rhizosphere microbial community in a temperate grassland soil Soil Biol Biochem 31:155-165 doi:https://doi.org/10.1016/S00380717(98)00118-7

Drinkwater LE, Wagoner P, Sarrantonio M (1998) Legume-based cropping systems have reduced carbon and nitrogen losses. Nature 396:262-265. https://doi.org/10.1038/24376

$\mathrm{Du} F$ et al (2013) Morhpological responses of six plant species to patchy habitat with different nitrogen concentrations using in-growth Core method. Pol J Ecol 61:257-269

Fornara DA, Tilman D (2008) Plant functional composition influences rates of soil carbon and nitrogen accumulation. J Ecol 96:314-322. https://doi.org/10.1111/j.13652745.2007.01345.x

Fuchs K, Hortnagl L, Buchmann N, Eugster W, Snow V, Merbold L (2018) Management matters: testing a mitigation strategy for nitrous oxide emissions using legumes on intensively managed grassland. Biogeosciences 15:5519-5543. https://doi.org/10.5194/bg-15-5519-2018

Grosso SJD et al (2000) General $\mathrm{CH}_{4}$ oxidation model and comparisons of $\mathrm{CH}_{4}$ oxidation in natural and managed systems. Global Biogeochem Cycles 14:999-1019. https://doi. org/10.1029/1999GB001226 
Hartmann AA, Buchmann N, Niklaus PA (2011) A study of soil methane sink regulation in two grasslands exposed to drought and $\mathrm{N}$ fertilization. Plant and Soil 342:265-275. https://doi.org/10.1007/s11104-010-0690-x

Haynes RJ (1980) Competitive aspects of the grass-legume association. Adv Agron 33:227-261. https://doi.org/10.1016 /S0065-2113(08)60168-6

Hodge A, Robinson D, Fitter A (2000) Are microorganisms more effective than plants at competing for nitrogen? Trends Plant Sci 5:304-308. https://doi.org/10.1016/S1360-1385(00 )01656-3

Høgh-Jensen H, Schjoerring JK (1997) Interactions between white clover and ryegrass under contrasting nitrogen availability: $\mathrm{N}_{2}$ fixation, $\mathrm{N}$ fertilizer recovery, $\mathrm{N}$ transfer and water use efficiency. Plant Soil 197:187-199. https://doi.org/10.1023 /a:1004289512040

Holland EA, Robertson GP, Greenberg J, Groffman P, Boone R, Gosz J (1999) Soil $\mathrm{CO}_{2}, \mathrm{~N}_{2} \mathrm{O}$, and $\mathrm{CH}_{4}$ exchange. In: Robertson GP, Bledsoe CS, Coleman DC, Sollins P (eds) Standard soil methods for long-term ecological research. Oxford University Press, New York, pp 185-201

Hothorn T, Bretz F, Westfall P (2008) Simultaneous inference in general parametric models. Biometrical J 50:346-363. https://doi.org/10.1002/bimj.200810425

Hütsch BW (1998) Methane oxidation in arable soil as inhibited by ammonium, nitrite, and organic manure with respect to soil pH. Biol Fertil Soils 28:27-35. https://doi.org/10.1007 /s003740050459

IPCC (2007) Summary for policymakers. . In: Solomon S et al. (eds) Climate change 2007: The physical science basis. In Contribution of Working Group I to the Fourth Assessment Report of the Intergovernmental Panel on Climate Change. Cambridge University Press: Cambridge, UK: 211-214

IPCC (2013) Climate change 2013: the physical science basis. Contribution of working group I to the fifth assessment report of the intergovernmental panel on climate change. Cambridge University Press, Cambridge, United Kingdom and New York, NY, USA. https://doi.org/10.1017 /CBO9781107415324

Jackson LE, Schimel JP, Firestone MK (1989) Short-Term Partitioning of Ammonium and Nitrate between Plants and Microbes in an Annual Grassland. Soil Biol Biochem 21: 409-415. https://doi.org/10.1016/0038-0717(89)90152-1

Jones DL, Healey JR, Willett VB, Farrar JF, Hodge A (2005) Dissolved organic nitrogen uptake by plants - an important $\mathrm{N}$ uptake pathway? Soil Biol Biochem 37:413-423. https://doi.org/10.1016/j.soilbio.2004.08.008

Kirwan L et al (2007) Evenness drives consistent diversity effects in intensive grassland systems across 28 European sites. J Ecol 95:530-539. https://doi.org/10.1111/j.13652745.2007.01225.x

Laidlaw AS, Christie P, Lee HW (1996) Effect of white clover cultivar on apparent transfer of nitrogen from clover to grass and estimation of relative turnover rates of nitrogen in roots. Plant Soil 179:243-253. https://doi.org/10.1007/bf00009334

Le Mer J, Roger P (2001) Production, oxidation, emission and consumption of methane by soils: a review. Eur J Soil Biol 37:25-50. https://doi.org/10.1016/S1164-5563(01)01067-6

Ledgard SF (2001) Nitrogen cycling in low input legume-based agriculture, with emphasis on legume/grass pastures. Plant Soil 228:43-59. https://doi.org/10.1023/a:1004810620983
Ledgard SF, Sprosen MS, Penno JW, Rajendram GS (2001) Nitrogen fixation by white clover in pastures grazed by dairy cows: Temporal variation and effects of nitrogen fertilization. Plant Soil 229:177-187. https://doi.org/10.1023 /a:1004833804002

Li Q, Yu PJ, Li GD, Zhou DW (2016) Grass-legume ratio can change soil carbon and nitrogen storage in a temperate steppe grassland. Soil Till Res 157:23-31. https://doi.org/10.1016/j. still.2015.08.021

Loreau M, Hector A (2001) Partitioning selection and complementarity in biodiversity experiments. Nature 412:72-76

Maire V, Gross N, Da Silveira PL, Picon-Cochard C, Soussana J-F (2009) Trade-off between root nitrogen acquisition and shoot nitrogen utilization across 13 co-occurring pasture grass species. Funct Ecol 23:668-679. https://doi.org/10.1111/j.13652435.2009.01557.x

Mawdsley JL, Bardgett RD (1997) Continuous defoliation of perennial ryegrass (Lolium perenne) and white clover (Trifolium repens) and associated changes in the composition and activity of the microbial population of an upland grassland. Soil Biol Fertil Soils 24:52-58. https://doi.org/10.1007 /bf01420220

McElroy MS, Papadopoulos YA, Glover KE, Dong Z, Fillmore SAE, Johnston MO (2017) Interactions between cultivars of legume species (Trifolium pratense L., Medicago sativa L.) and grasses (Phleum pratense L., Lolium perenne L.) under different nitrogen levels. Can J Plant Sci 97:214-225. https://doi.org/10.1139/cjps-2016-0130

Migliorati MD, Bell M, Grace PR, Scheer C, Rowlings DW, Liu S (2015) Legume pastures can reduce N2O emissions intensity in subtropical cereal cropping systems. Agric Ecosyst Environ 204:27-39. https://doi.org/10.1016/j. agee.2015.02.007

Mortenson MC, Schuman GE, Ingram LJ (2004) Carbon sequestration in rangelands Interseeded with yellow-flowering alfalfa (Medicago sativa ssp. falcata). Environ Manage 33: S475-S481. https://doi.org/10.1007/s00267-003-9155-9

Mueller KE, Hobbie SE, Tilman D, Reich PB (2013) Effects of plant diversity, $\mathrm{N}$ fertilization, and elevated carbon dioxide on grassland soil $\mathrm{N}$ cycling in a long-term experiment. Global Change Biol 19:1249-1261. https://doi.org/10.1111 /gcb.12096

Mulder CPH, Jumpponen A, Hogberg P, Huss-Danell K (2002) How plant diversity and legumes affect nitrogen dynamics in experimental grassland communities. Oecologia 133:412421. https://doi.org/10.1007/s00442-002-1043-0

Naudin C, Corre-Hellou G, Pineau S, Crozat Y, Jeuffroy MH (2010) The effect of various dynamics of $\mathrm{N}$ availability on winter pea-wheat intercrops: crop growth, $\mathrm{N}$ partitioning and symbiotic N-2 fixation. Field Crops Res 119:2-11. https://doi.org/10.1016/j.fcr.2010.06.002

Niklaus P, Wardle D, Tate K (2006) Effects of plant species diversity and composition on nitrogen cycling and the trace gas balance of soils. Plant and Soil 282:83-98. https://doi. org/10.1007/s11104-005-5230-8

Niklaus PA, Le Roux X, Poly F, Buchmann N, Scherer-Lorenzen M, Weigelt A, Barnard RL (2016) Plant species diversity affects soil-atmosphere fluxes of methane and nitrous oxide. Oecologia 181:919-930. https://doi.org/10.1007/s00442016-3611-8 
Nyfeler D, Huguenin-Elie O, Suter M, Frossard E, Lüscher A (2011) Grass-legume mixtures can yield more nitrogen than legume pure stands due to mutual stimulation of nitrogen uptake from symbiotic and non-symbiotic sources agriculture. Ecosyst Environ 140:155-163. https://doi.org/10.1016 /j.agee.2010.11.022

Oertel C, Matschullat J, Zurba K, Zimmermann F, Erasmi S (2016) Greenhouse gas emissions from soils A review. Chem ErdeGeochem 76:327-352. https://doi.org/10.1016/j. chemer.2016.04.002

Ofosubudu KG, Noumura K, Fujita K (1995) N-2 fixation, N transfer and biomass production of soybean cv Bragg or its Supernodulating Nts 1007 and Sorghum mixed-cropping at 2 rates of N Fertilizer. Soil Biol Biochem 27:311-317. https://doi.org/10.1016/0038-0717(94)00177-3

Orwin KH, Buckland SM, Johnson D, Turner BL, Smart S, Oakley S, Bardgett RD (2010) Linkages of plant traits to soil properties and the functioning of temperate grassland. J Ecol 98:1074-1083. https://doi.org/10.1111/j.13652745.2010.01679.x

Ostonen I et al (2007) Specific root length as an indicator of environmental change plant biosystems - an international journal dealing with all aspects of plant. Biology 141:426442. https://doi.org/10.1080/11263500701626069

Paynel F, Lesuffleur F, Bigot J, Diquelou S, Cliquet JB (2008) A study of (15) $\mathrm{N}$ transfer between legumes and grasses agronomy for sustainable. Development 28:281-290. https://doi. org/10.1051/agro:2007061

Personeni E, Loiseau P (2005) Species strategy and N fluxes in grassland soil. Eur J Agron 22:217-229. https://doi. org/10.1016/j.eja.2004.02.007

Pinheiro J, Bates D, DebRoy S, Sarkar D, Team\} RC (2019) \{nlme\}: Linear and Nonlinear Mixed Effects Models

Pirhofer-Walzl K, Rasmussen J, Høgh-Jensen H, Eriksen J, Søegaard K, Rasmussen J (2012) Nitrogen transfer from forage legumes to nine neighbouring plants in a multispecies grassland. Plant and Soil 350:71-84. https://doi. org/10.1007/s11104-011-0882-z

Poorter H, Van der Werf A, Atkin OK, Lambers H (1991) Respiratory energy requirements of roots vary with the potential growth rate of a plant species. Physiologia Plantarum 83:469-475. https://doi.org/10.1111/j.1399-3054.1991. tb00122. $\mathrm{x}$

R Development Core Team (2017) R: a language and environment to statistical computing. R Foundation for Statistical Computing, Vienna, Austria

Rasmussen J, Gylfadottir T, Loges R, Eriksen J, Helgadottir A (2013) Spatial and temporal variation in N transfer in grasswhite clover mixtures at three Northern European field sites. Soil Biol Biochem 57:654-662. https://doi.org/10.1016/j. soilbio.2012.07.004

Rime T, Niklaus PA (2017) Spatio-temporal dynamics of soil CH4 uptake after application of $\mathrm{N}$ fertilizer with and without the nitrification inhibitor 3,4-dimethylpyrazole phosphate (DMPP). Soil Biol Biochem 104:218-225. https://doi. org/10.1016/j.soilbio.2016.11.001

Smith KA, Ball T, Conen F, Dobbie KE, Massheder J, Rey A (2003) Exchange of greenhouse gases between soil and atmosphere: interactions of soil physical factors and biological processes. Eur J Soil Sci 54:779-791. https://doi.org/10.1046 j.1351-0754.2003.0567.x
Smith RS et al (2008) Long-term change in vegetation and soil microbial communities during the phased restoration of traditional meadow grassland. J Appl Ecol 45:670-679. https://doi.org/10.1111/j.1365-2664.2007.01425.x

Spehn EM, Joshi J, Schmid B, Diemer M, Korner C (2000) Above-ground resource use increases with plant species richness in experimental grassland ecosystems. Funct Ecol 14: 326-337

Spehn EM et al (2002) The role of legumes as a component of biodiversity in a cross-European study of grassland biomass nitrogen. Oikos 98:205-218. https://doi.org/10.1034/j.16000706.2002.980203.x

Sun $\mathrm{H}$ et al (2013) The effects of plant diversity on nitrous oxide emissions in hydroponic microcosms. Atmos Environ 77: 544-547. https://doi.org/10.1016/j.atmosenv.2013.05.058

Suter M, Connolly J, Finn JA, Loges R, Kirwan L, Sebastià M-T, Lüscher A (2015) Nitrogen yield advantage from grasslegume mixtures is robust over a wide range of legume proportions and environmental conditions. Global Change Biology 21:2424-2438. https://doi.org/10.1111/gcb.12880

Suwanwaree P, Robertson GP (2005) Methane oxidation in Forest. Successional, No-till Agric Ecosyst Soil Sci Soc Am J 69: 1722-1729. https://doi.org/10.2136/sssaj2004.0223

Thilakarathna MS, McElroy MS, Chapagain T, Papadopoulos YA, Raizada MN (2016) Belowground nitrogen transfer from legumes to non-legumes under managed herbaceous cropping systems A review. Agronomy Sustain Dev 36:16. https://doi.org/10.1007/s13593-016-0396-4

Thomson AJ, Giannopoulos G, Pretty J, Baggs EM, Richardson DJ (2012) Biological sources and sinks of nitrous oxide and strategies to mitigate emissions. Philos T R Soc B 367:11571168. https://doi.org/10.1098/rstb.2011.0415

Tilman D, Reich PB, Knops J, Wedin D, Mielke T, Lehman C (2001) Diversity and productivity in a long-term grassland experiment. Science 294:843-845. https://doi.org/10.1126 /science.1060391

Topp E, Pattey E (1997) Soils as sources and sinks for atmospheric methane. Can J Soil Sci 77:167-178

Van Der Krift TAJ, Berendse F (2001) The effect of plant species on soil nitrogen mineralization. J Ecol 89:555-561. https://doi.org/10.1046/j.0022-0477.2001.00580.x

van Ruijven J, Berendse F (2005) Diversity-productivity relationships: initial effects, long-term patterns, and underlying mechanisms. Proc National Acad Sci United States of America 102:695-700. https://doi.org/10.1073 /pnas.0407524102

Wickham H (2011) The split-apply-combine strategy for data analysis. J Stat Softw 40:1-29

Wu G-L, Liu Y, Tian F-P, Shi Z-H (2017) Legumes functional group promotes soil organic carbon and nitrogen storage by increasing plant diversity. Land Degrad Dev 28:1336-1344. https://doi.org/10.1002/ldr.2570

Zuur AF, Ieno EN, Walker NJ, Saveliev AA, Smith GM (2009) Mixed effects models and extensions in ecology with R. 1 edn. Springer-Verlag, New York. https://doi.org/10.1007 /978-0-387-87458-6

Publisher's note Springer Nature remains neutral with regard to jurisdictional claims in published maps and institutional affiliations. 